Bristol more than Lord Justice Sir Edward Fry, F.R.S., the great international lawyer, who was born in Union Street, Bristol, and was a local naturalist of national reputation; John Samuel Budgett was a well-known local naturalist; while the third meeting in Bristol of the British Associa- tion, which took place in 1898 , will always be remembered for the remarkable presidential address of Sir William Crookes, in which he directed attention to the limitations to the world's wheat supply and forecast the production of nitrogenous fertilisers from the air.

\title{
Recent Hydro-Electric Developments in the Alps and the Apennines.
}

\section{By Dr. Brysson Cunningham.}

THE widely extended and systematic exploita1 tion within recent years of the valuable water power resources of Switzerland and Italy, hitherto lying latent among the mountain chains of the Alps and the Apennines, is one of the most striking features in connexion with the modern industrial and commercial developments of the countries in question, and it has been, and is being, attended by economic repercussions affecting various nationalities, including our own. Coal, the usual source of energy for power purposes where it can be mined, is lacking as a natural deposit, and, in the past, manufacturers using mineral fuel have had to rely in the main on importations from abroad, a very considerable portion of which came from Great Britain (South Wales and the Tyne district). The acute experience during the War, when these external supplies were cut off, brought home to the Swiss and Italian peoples the necessity of finding some internal means of making good a deficiency which tended to hamper, and even to paralyse, their industrial activities and placed them at the mercy of foreign interests. Not surprisingly, their attention was directed to the great potential value of the streams and lakes in the mountainous districts, where an untold quantity of water lay ready for utilisation and was capable, in a very large measure, of meeting commercial and industrial needs. These elevated reservoirs and mountain streams could be harnessed so as to produce electric current, which, in turn, could be distributed far and wide to suitable points of application.

The visitor to northern Italy and Switzerland at the present time cannot fail to notice the growing network of transmission lines which is spreading over the face of the country, scaling mountain flanks and ridges, traversing hills, valleys, and plains, and linking up cities and centres of population with an enormous spider's-web of copper and aluminium wire. Where, in past days, the landscape's most conspicuous artificial features were picturesque campaniles and church steeples, there are now to be seen, in challenging competition, lofty steel-framed pylons and standards, ranged in long files which, like the telegraph poles alongside a railway track, attend the traveller throughout his journeys.

The utilisation of water power for the generation of electricity, or rather its systematic exploitation for the purpose on a large scale, is a comparatively recent enterprise. Until the close of last century electricity was generated almost entirely by steam power. Canada-a country similarly handicapped to Italy and Switzerland in regard to its lack of natural coal deposits-which has now no less than six million water horse power harnessed to its electric generating stations, possessed in 1900 less than 250,000 realised horse power. In Italy, pioneer steps were first undertaken towards the end of the 'eighties, when in 1888 the city of Trento installed a plant of $500 \mathrm{kw}$., and between 1892 and 1895, when at Tivoli and Paderno scarcely less modest installations were inaugurated, the former to supply current to Rome at 5000 volts and the latter to Milan at 13,000 volts. It may be affirmed that these small undertakings marked the initiation in Europe of the great movement in hydro-electric exploitation which is so actively in progress at the present time throughout the world and has revolutionised in no small measure the methods and operations of manufacture and industry.

In this and two succeeding articles it is proposed to give a brief description of the conditions and present position in regard to hydro-electric developments in Switzerland and Italy, and to set down certain personal impressions formed during a recent series of visits to some of the leading and most modern installations.

Both countries have mountain systems of great magnitude and extent. The towering heights attained by the ranges have naturally a very marked influence in conferring a notable degree of head, or pressure, on supplies of water which can be collected, diverted, and utilised for power purposes. In this respect, however, it is desirable to point out a distinction between the two classes of mountain ranges. The essential characteristic of the Alps is their abundance of glaciers, with extensive areas of frozen snow and ice, which cover their summits and topmost slopes practically in perpetuity. From the gradual and periodical melting of these masses of ice and snow come the streams and waterfalls which constitute so charming a feature of the landscape. But the flow is intermittent and limited to those seasons of the year in which the temperature is sufficiently high to cause thawing. In other words, it is only during the summer months that supplies of flowing water from these sources are available. During the rest of the year they are imprisoned in a solid state.

Fig. 1 shows a view of the Piz Palü and the Palü Glacier in the Bernina Range, one of the sources of supply of the Brusio Power Works in the Canton of the Grisons, Switzerland.

In the Apennines, on the other hand, there is an absence of glaciers and very rarely do these heights

No. 3175, VoL. 126] 


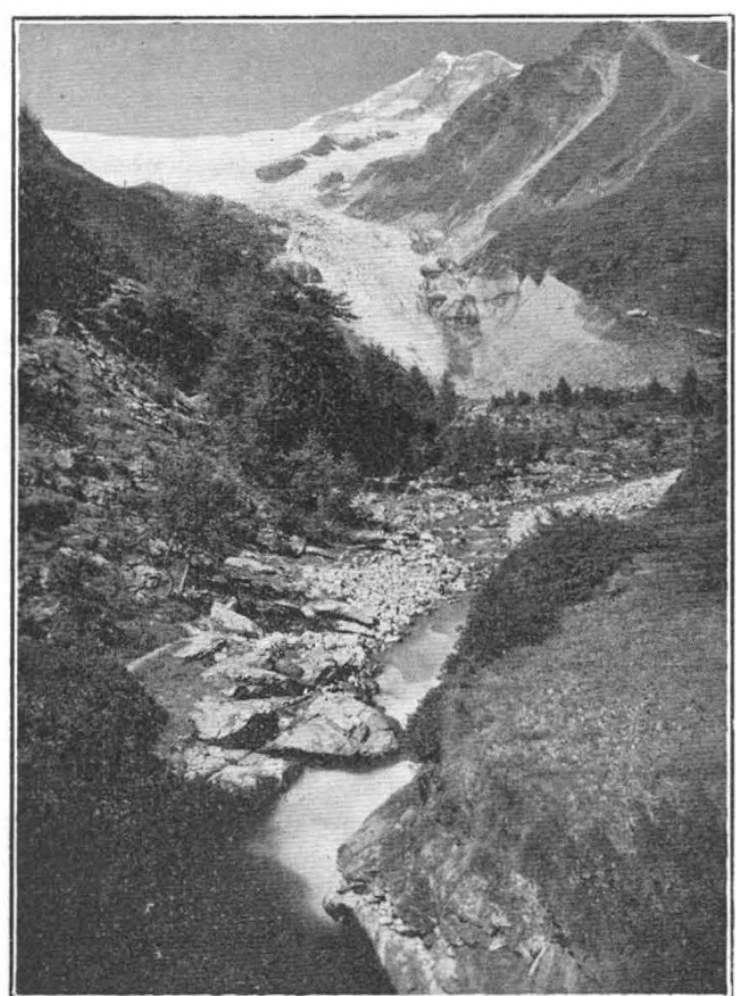

FIG. 1.--Piz Palii and Palü Glacier, Bernina Range, Canton of the Grisons, Switzerland. By courtesy of the Brusio Kraftwerke, Poschiavo.

reach the level of perpetual snow. The consequence is that, as regards water supplies, an entirely different regimen prevails. It is not from glaciers and snowfields that the watercourses of the defiles and valleys are fed, but from the ordinary rainfall, which is seasonal and chiefly in evidence during the autumn and winter, whereas the summer precipitation is slight.

The difference may be summed up by saying that the hydroelectric installations among the Alps are, in general, actuated by lofty heads and small (even, in some cases, exiguous) supplies, with a service which is only fully effective during the sum. mer, whereas those among the Apennines have a more moderate fall with better and more copious supplies, frequently in association with impounding reservoirs in the lower levels, the seasonal activity being most pronounced during the autumn and winter.

Impounding reservoirs, however, are not limited to the Apennine regions: they are also a feature of certain Alpine installations, though in that case they are located at considerably

No. 3175, VoL. 126] increased heights, and their area is naturally more circumscribed. Moreover, they have been formed under greater constructional difficulties than those on the lower slopes, which, although in some cases requiring dams of greater length, are more readily and easily accessible. The impediments in the way of the conveyance of material and the carrying on of works in the higher regions are obviously very great and the cost of such operations is correspondingly heavy.

In the formation of storage reservoirs, regard has naturally been had to the possibilities of utilising the configuration of the district to the best advantage. Despite the existence, however, among the mountain ranges of quite a number of natural lakes which form admirable reservoirs of water suitable for power purposes, the physical conditions have not always been favourable, and, the distribution being irregular, in many cases, use has had to be made of other sites which have required extensive constructional operations in order to develop them adequately as basins of supply. Some of these artificial basins, especially those of low or moderate altitude, are of remarkable size ; there are about fifty or so in Italy alone, each containing more than one million cubic metres of water. Perhaps the most notable of recent years is the reservoir of Tirso, in Sardinia, which has a maximum capacity of about 400 million cubic metres.

One of the earliest examples is the reservoir at Cismon, in the province of Belluno, by means of which the Società Adriatica d'Elettricità has been able to impound four million cubic metres. It possesses some interesting features. Constructed between 1905 and 1908, and the first of its type in

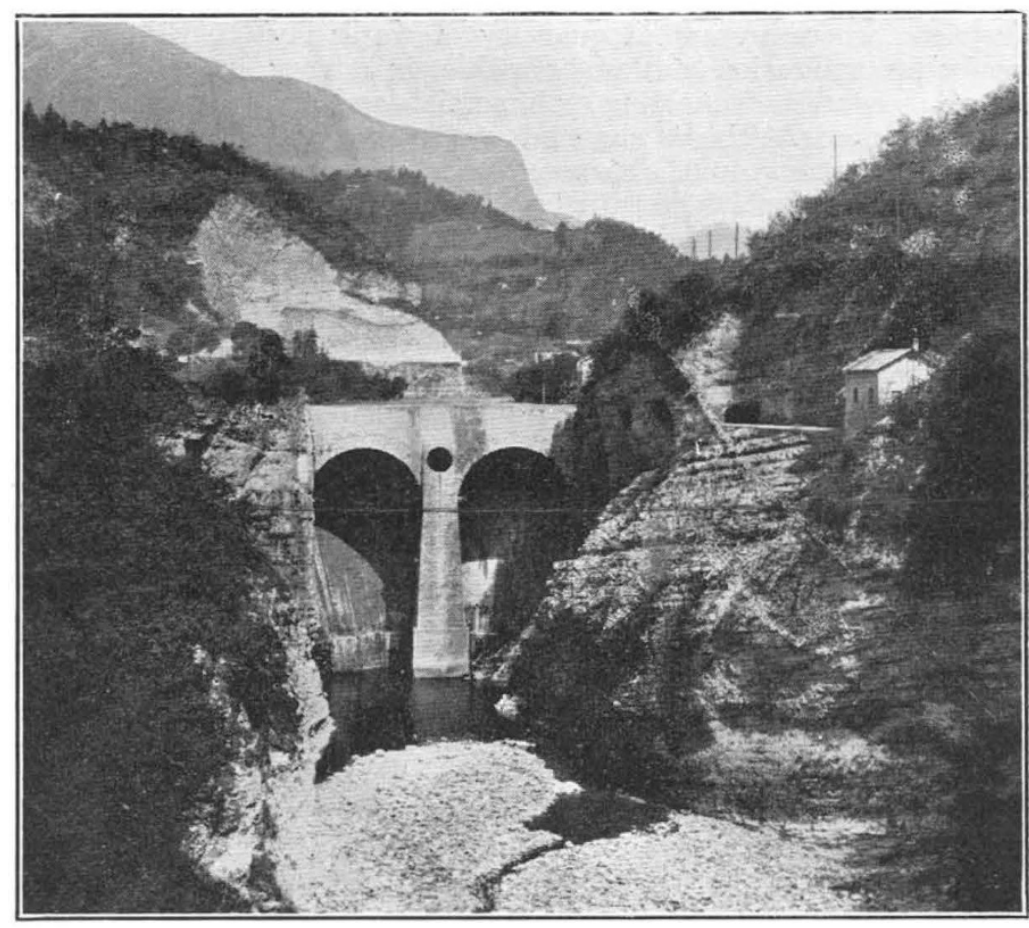

FIG. 2.-Cismon Dam. By courtesy of the Società per l' Utilizzazione delle Forze Idrauliche delle Veneto. 
Italy, the masonry dam, which is shown in Fig. 2, is in the form of a slender arch supported by rock abutments on each side so closely adjacent that the chord of the are is only 40 metres in length. The thickness of the dam at the top is 3 metres, increasing to 12 metres at the base. The height is 44 metres. The overflow, sometimes 2 metres in depth, passes over a rectilinear crest supported by the flanks of the dam and a central pier. The conduit to the power station (shown in Fig. 3) takes the form of a tunnel $1 \frac{1}{2}$ kilometres in length, at the end of which are two pressure tubes of 1.9 metre diameter. These, with a fall of 52 metres and a flow of 18 cubic metres per second, feed two generators, the joint capacity of which is just under 10,000 horse power.

Another point to which attention may be directed as characteristic of both Alpine and Apennine installations, arising out of the intermission of their supplies, is that for the purpose of securing constant supplies of power it has been necessary to supplement them in a number of cases by 'thermic' or steam generating stations, in which current is generated by power derived from the consumption of fuel. Thus it will be seen that, as distinct from purely hydro-electric power stations, such as those in eastern Canada, which are more or less in constant action under the energy derived from streams and rivers at low altitudes with plentiful supplies of water, the power stations of northern Italy are worked in conjunction with thermic stations which come into operation when the natural water power is suspended or is insufficient. These two sets of stations have to be connected and linked up in a com. pensatory system, which complicates matters a little more than would be the case if the energy were forthcoming from a single source. The six leading hydro-electric systems in the Italian peninsula, namely, the S.I.P. (Società Idroelettrica Piemonte), Edison, Adamello, Adriatica, Central and South Groups, have six thermic stations, at Turbigo, Genoa, Raconga, Marghera (Venice), Leg. horn, and Naples respectively.

Attempts have been made from time to time to determine within reasonably close limits the total available supply of hydraulic energy in various countries. In all computations of this kind there is much scope for error, due to the unreliability and insufficiency of the data at hand. Conclusions, therefore, have necessurily been of the nature of mere approximations, subject to correction as further investigations have been made and the results of actual utilisations have become known. At the present time, estimates are still too vague to permit of any close or rigorous figures, but for the purposes of this notice it may be said that such statistics as are published lead to the conclusion that the available water horse power of Italy is of the order of five to six millions, ${ }^{1}$ and that of Switzerland rather less-say four millions. ${ }^{2}$ These figures must be taken with reserve; they are probably, almost certainly, under-estimates, but they may serve as the basis of an interesting comparison with similar estimates applicable to Canada, where, as noted in a recent article in NATURE, ${ }^{3}$ the available horse power is calculated to exceed forty millions. On the other hand, the area of Canada is more than thirty times as great as Italy and 233 times as great as Switzerland. Accordingly it will be seen that, despite the magnitude and impressiveness of the developments which have been proceeding on the North American continent, the potential intensity of development on an area basis is much greater in the European countries.

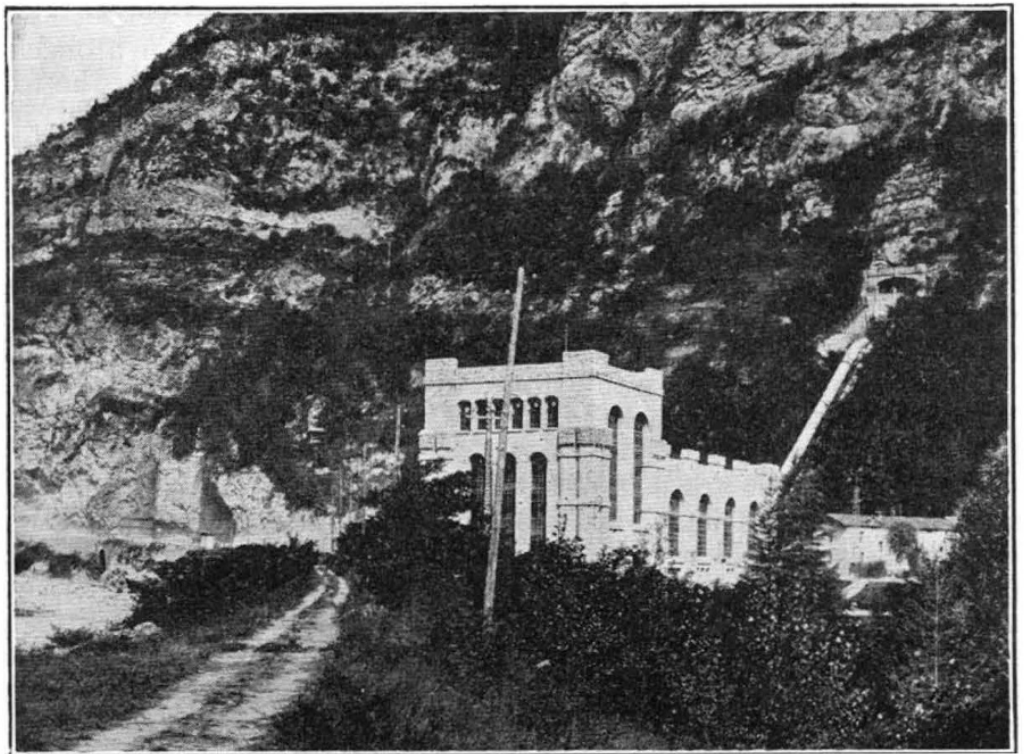

tion. By courtesy of the società per l' Utilizzazione delle Forze Idrsuliche del Veneto.

During 1929, some 400,000 additional water horse power was installed in new, or extended, hydro-electric stations in Italy, bringing the aggregate of installations up to about $4 \frac{1}{2}$ million horse power. The latest available figures for Switzerland indicate that some $2 \frac{1}{2}$ million horse power had been realised in various installations up to the end of 1929. It must be admitted, however, that the difficulties in the way of instituting an exact census of all installations, large and small, public and private, direct acting and transmissional, are such that the returns, while substantially correct, may not be quite precisely so. At a stage when progress is rapid and the situation changes from month to month, absolute accuracy is, perhaps, of no great account.

"Vide, Table IV., "Power Resources of the World"; published by London World Power Conference, 1929.

This is the ofticisl estimste of the Sulss Service des Eaux as contsined in the Rapport du Conseil Feddral sur sa Gestion en 1929. A much higher flgure is given in the London World Power Conference much high

Meport. 31, 1930. 